\title{
Utilization Of Industrial Waste Pulp And Palm Oil On Growth And Results Of Corn (Zea Mays L) On Peat
}

\author{
Marlina, Intan Sari, Elfi Yenny Yusuf, Yoyon Riono, Mulono Apriyanto
}

\begin{abstract}
This study aims to determine the merits of various industrial waste pulp and palm oil as well as getting the most appropriate formulation on growth and yield of maize varieties Earth-3 and NK-212 in peatlands. Research using split plot design using the design of completely randomized design (CRD) and each treatment was repeated 3 times. Varieties as the main plot consists of: (V1): Varieties of Earth-3, (V2): Varieties of NK-212. Treatment subplot, consisting of six formulations ameliorant, namely: F1 (60\% OPEF $+20 \%$ GPB $+10 \%$ Dregs $+10 \%$ Fly ash), F2(60\% OPEF + 10\% GPB + 20\% Dregs $+10 \%$ Fly ash $),$ F3 $(60 \%$ OPEF $+10 \%$ GPB $+10 \%$ Dregs $+20 \%$ Fly ash $)$, F $4(40 \%$ OPEF $+30 \%$ GPB $+10 \%$ Dregs $+20 \%$ Fly ash $)$, F5(40\% OPEF $+20 \%$ GPB $+30 \%$ Dregs $+10 \%$ Fly ash) and F6(40\% OPEF $+10 \%$ GPB $+20 \%$ Dregs $+30 \%$ Fly ash). The data obtained were statistically analyzed using analysis of variance (ANOVA) followed by HSD test at $5 \%$ level. The results showed that various formulations of industrial waste pulp and palm oil gave similar results to the root dry weight, dry weight of straw, hay root ratio, the diameter of the cob, corncob, corncob without the husk and dry seed weight. It can be seen from the cob generated a large and long and close cob husk well $( \pm 98 \%)$, beans straight line with a number of seed rows $15-16$ rows, as well as a uniform crop diversity, is in conformity with the description.
\end{abstract}

Keyword : Variety, Corn, Industrial Waste, Peat, Utility, Corcobs.

\section{INTRODUCTION}

Around $50 \%$ of the raw material for poultry feed comes from corn, it is estimated that the animal feed industry in Indonesia is able to absorb approximately 200,000 tons of dry shelled corn every month [1]. Corn production in Riau according to data from the Central Statistics Agency (BPS) of Riau Province in 2013-2015 continued to decline. In 2013 corn production in Riau amounted to 28,052 tons of dry shelled, significantly decreased by 3,381 tons or $10.76 \%$ compared to 2012 [1]. In terms of productivity in 2014 production decreased again by $0.48 \%$, from 23.88 quintals per hectare in 2013 to 23.76 quintals per hectare in 2014[2]. The BPS data shows that corn production in Riau is still low and needs to be increased because it has not been able to keep up with market demand. Productive land (minerals) is increasingly limited, so agricultural extension is carried out on marginal land (peat). However, the use of peatlands for agriculture is faced with several constraints, namely: thickness and level of decomposition, low macro and micro nutrient status, soil acidity and organic acids, presence of pyrite layers and poor water management, so that proper soil management is needed. and the addition of fertilizers and ameliorant to improve soil conditions for plant growth[3]. Amelioration of peat soils is needed because peat has low saturation base (KB), low pH and low macro and micro nutrient content so that ameliorant treatment is needed as soil ameliorant to improve soil fertility through improvement of physical, chemical and biological soil properties. The oil palm plantation industry and the processing of paper (pulp) in Riau quite a lot so that the waste produced is also quite high.

- Marlian. Universitas Islam Indragiri.Email :mlina7373@yahoo.co.id

- Intan Sari. Universitas Islam Indragiri. Email intansariunisi@gmail.com

- Elfi Yenny Yusuf. Universitas Islam Indragiri. Email elfiyenny25@gmail.com.

- Yoyon Riono. Universitas Islam Indragiri. Email yoyonriono353@gmail.com

- Mulono Apriyanto. Universitas Islam Indragiri. Email mulonoapriyanto71@gmail.cim
Oil palm plantation waste such as Oil Palm Empty Fruit Bunch (TKKS) and Oil Palm Bunch Ash (ATKS), as well as pulp waste such as dregs and fly ash, contain high enough nutrients so that it has the potential to be used as ameliorant for peat soil ameliorant. TKKS compost contains high potassium $(\mathrm{K})$, which is $4-6 \%$, and other nutrients such as phosphorus (P); 0.2-0.4\%, Nitrogen (N); $2-3 \%$, Calcium (Ca); $1-2 \%$, Magnesium (Mg); 0.8-1.0\% and $\mathrm{C} / \mathrm{N} ; 15.03 \%[4]$. Oil Palm Bunches (ATKS) can increase soil $\mathrm{pH}$ and have a significant effect on increasing levels of interchangeable potassium (k-dd) [4]. Fly ash contains nutrients needed by plants such as $\mathrm{Zn}, \mathrm{Ca}, \mathrm{Mg}, \mathrm{K}$ and $\mathrm{P}$, so they can meet the needs of plant nutrients. The dominant elements in dregs are Ca.44\%, SiO2; 3.36\%, Al2O3; 3.38\%, and $\mathrm{Fe} 2 \mathrm{O} 3 ; 0.046 \%[5]$. Complete nutrient requirements needed by plants can be fulfilled by formulation or mixing to meet each nutrient needed by plants, so that the different nutrient content of each ameliorant can complement each other, and nutrient requirements needed by plants on peat soils can be fulfilled[4]. The study aims to determine the benefits of pulp and palm oil industry waste in various formulations on the growth and yield of maize Pertiwi-3 and NK-212 varieties in peatlands. Based on the description above it is necessary to conduct research to determine the effect of various industrial waste formulations in increasing the growth and yield of corn in peatlands[6].

\section{MATERIALS AND METHODS}

This research was conducted in Tembilahan Hulu Village Tembilahan Hulu Subdistrict, Indragiri Hilir Regency, Riau Province, from May to September 2015 according [1]. The study used a split plot design with 2 factors. Varieties as the main plot are $\mathrm{V} 1=$ Variety of Pertiwi-3 and V2 = Variety of NK 212, as well as ameliorant formulations as subplots. namely: F1 $(60 \%$ TKKS + 20\% ATKS + 10\% Dregs + 10\% Flyash), F2 $(60 \%$ TKKS $+10 \%$ ATKS $+20 \%$ Dregs $+10 \%$ Flyash $)$, F3 $(60 \%$ TKKS $+10 \%$ ATKS $+10 \%$ Dregs $+20 \%$ Flyash $)$, F4 $(40 \%$ TKKS $+30 \%$ ATKS $+10 \%$ Dregs $+20 \%$ Flyash $)$, F5 (40\% TKKS + 20\% ATKS + 30\% Dregs + 10\% Flyash), and F6 (40\% TKKS + 10\% AJKS + 20\% Dregs + 30\% Flyash). According [1] Observations were made on the components of production of each sample of the plant that has been 
determined. include: root dry weight, straw dry weight, root straw ratio, ear diameter, ear weight with cob, ear weight without ear and ear weights. All data from each observation variable were statistically analyzed while differences between treatments were carried out by BNJ further tests at the $5 \%$ level.

\section{RESULTS AND DISCUSSION}

The results of the soil analysis before being treated (Table 1) showed that the $\mathrm{pH}$ (4.84) was acidic, KB (2.84) was very low, and the base cations ( $\mathrm{Ca}$ and $\mathrm{Mg}$ ) were classified as very low and the C-organic content (30) , 2), N-total (1.30) and CEC (97.8) are classified as very high, so it can be concluded that the peat soil used has a low fertility rate, so that the nutrients needed by plants become unavailable. The provision of pulp and palm oil industry waste as ameliorant is expected to be able to increase the fertility of peat so it supports the growth of corn. Table 1. shows that the $\mathrm{pH}$ of the peat soils used was included in the acid criteria. This is due to the high content of $\mathrm{H}+$ ions from the organic acids making up peat which is easily dissociated, especially in the carboxylate $(-\mathrm{COOH})$ and phenolate $(\mathrm{C} 6 \mathrm{H} 4 \mathrm{OH})$ groups.

Table 1. Chemical Properties of Soil Research

\begin{tabular}{|l|c|c|}
\hline Sifat Kimia Tanah & Nilai & Kriteria \\
\hline pH H2O & 4,84 & Sour \\
pH KCl & 3,92 & Sour \\
C Organik(\%) & 30,2 & Very high \\
N-Total $(\%)$ & 1,30 & Very high \\
C/N & & \\
$P$ Total $(\mathrm{g} / \mathrm{kg})$ & 23,3 & High \\
K Total $(\mathrm{g} / \mathrm{kg})$ & 0,51 & High \\
Tersedia $(\mathrm{g} / \mathrm{kg})$ & 0,77 & Very high \\
Kation basa $(\mathrm{NH} 4 \mathrm{OAc} \mathrm{pH} 7)$ & 2,61 & Very high \\
Ca-dd $(\mathrm{Cmol} / \mathrm{kg})$ & 1,86 & Very low \\
Mg-dd $(\mathrm{Cmol} / \mathrm{kg})$ & 0,53 & Low \\
K-dd $(\mathrm{Cmol} / \mathrm{kg})$ & 0,32 & Low \\
Na-dd $(\mathrm{Cmol} / \mathrm{kg})$ & 0,07 & Moderate \\
KTK $(\mathrm{Cmol} / \mathrm{kg})$ & 97,8 & Very low \\
KB (\%) & 2,84 & Very high \\
\hline
\end{tabular}

The content of C-organic, $\mathrm{N}$-total and $\mathrm{C} / \mathrm{N}$ ratio is very high, so that $\mathrm{N}$ is not available for plants because $\mathrm{N}$ is still an organic material for peat compilation. Nelvia et al., (2010) states that if the total $\mathrm{N}$ content, $\mathrm{C}$-organic content is high and the $\mathrm{C} / \mathrm{N}$ ratio is also high, it means that $\mathrm{N}$ is a compiler of peat organic material and is not available for plants. The availability of total $P$ and $P$ is very high and high, this is due to the total $P$ still in the form of organic $P$ in the organic material making up peat. The high $P$ available is due to the addition of alkaline nutrients from overflowing river water because the study area is near the river and is still flooded by tides. Besides that the peat used is peat with sapric maturity level so that the organic material has been decomposed further and has been mineralized, so that the $\mathrm{P}$ element is released. Rachim (1995) states that the increase in available $P$ is related to the decomposition and mineralization of organic matter, so that the $P$ element becomes detached. The content of $\mathrm{Ca}$-dd, Mg-dd and $\mathrm{Na}$-dd is classified as low and very low, $\mathrm{K}$-dd is moderate, CEC is very high and $\mathrm{KB}$ is very low. This is caused by the dissociation of carboxyl groups which release $\mathrm{H}+$ into solution and colloids so that they become negatively charged. Ratmini (2012) states that the high CEC is caused by peat soil colloids which are negatively charged, and contain many organic acids with carboxyl and phenolic groups. The higher the carboxyl and phenolic groups, the higher the peat soil CEC. Peat soils characterized by CEC are very high, but the percentage of KB is very low, making it difficult to absorb nutrients, especially bases needed by plants. This was also stated by Nelvia et al., (2010) that the value of CEC is very high but low KB will inhibit the supply of nutrients, especially $\mathrm{K}, \mathrm{Ca}$ and $\mathrm{Mg}$.

\section{Soil Reaction After Research}

Table 2 shows that the various ameliorant formulations on peat soils for maize of the Pertiwi-3 and NK-212 varieties had less effect on increasing $\mathrm{pH}$ compared to the initial $\mathrm{pH}$ (4.84), the increase in $\mathrm{pH}$ only ranged from 0.04 to 0.36 .

Table 2. $\mathrm{pH}(\mathrm{H} 2 \mathrm{O})$ Peat soils applied to various Ameliorant Formulations After Harvesting Maize Varieties Pertiwi-3 and NK-212.

\begin{tabular}{|c|c|}
\hline Amelioran Formulation & $\mathrm{pH}(\mathrm{H} 2 \mathrm{O})$ \\
\hline $\begin{array}{l}\text { FF1(60\% TKKS + } 20 \% \text { ATKS }+10 \% \text { Dregs }+ \\
10 \% \text { Fly ash })\end{array}$ & 4,88 \\
\hline $\begin{array}{l}\text { FF2 }(60 \% \text { TKKS }+10 \% \text { ATKS }+20 \% \text { Dregs }+ \\
10 \% \text { Fly ash) }\end{array}$ & 4,97 \\
\hline $\begin{array}{l}\text { FF3(60\% TKKS + } 10 \% \text { ATKS }+10 \% \text { Dregs }+ \\
20 \% \text { Fly ash })\end{array}$ & 5,06 \\
\hline $\begin{array}{l}\text { FF } 4(40 \% \text { TKKS }+30 \% \text { ATKS }+10 \% \text { Dregs }+ \\
20 \% \text { Fly ash })\end{array}$ & 5,08 \\
\hline $\begin{array}{l}\text { FF5(40\% TKKS + } 20 \% \text { ATKS }+30 \% \text { Dregs }+ \\
10 \% \text { Fly ash })\end{array}$ & 5,02 \\
\hline $\begin{array}{l}\text { FF6 }(40 \% \text { TKKS }+10 \% \text { ATKS }+20 \% \text { Dregs }+ \\
30 \% \text { Fly ash })\end{array}$ & 5,20 \\
\hline
\end{tabular}

The highest $\mathrm{pH}$ increase tends to occur in the $\mathrm{F} 6$ formulation with the highest composition of dregs and fly ash, $20 \%$ dregs and $30 \%$ fly ash. This is caused by the presence of lime in the dregs and fly ash which is quite high in the form of $\mathrm{CaO}$ respectively $410300 \mathrm{mg} / \mathrm{kg}$ and $66700 \mathrm{mg} / \mathrm{kg}$. Very high CaO content is a source of $\mathrm{Ca}$, because $\mathrm{CaO}$ is very effective for increasing soil $\mathrm{pH}$ as a substitute for lime. The results of [7] research showed that pulp \& paper waste is an effective material in increasing $\mathrm{pH}$ as a substitute for lime, because the Ca element contained in pulp \& paper waste can improve plant growth environment. Table 3 shows that the results of laboratory analysis of pulp and palm oil industry wastes have high nutrient content so that it has the potential to be used as ameliorant for peat soil ameliorants. Dried Straw Weight, Dried Root Weight and Root Straw RatioThe administration of various ameliorant formulations on peat soils planted with maize Pertiwi-3 and NK212 varieties have the same effect on all observed variables. This can be seen from the performance of straw, roots, cob diameter, the number of seeds per row and the number of rows of seeds per cob that show almost the same shape as can be seen in Figures 1 and 2. During the vegetative phase, the decomposition and dissolution of nutrients from ameliorant continues, so that the nutrients needed by corn plants become available, because it has undergone decomposition of the results of overhaul of organic matter by microorganisms, such as $\mathrm{P}, \mathrm{K}$ and $\mathrm{Ca}$ which are very instrumental in root development.

Table 3 Results of the Analysis of the Chemical Properties of the Pulp and Palm Oil Industry Waste

\begin{tabular}{|c|c|c|c|c|}
\hline \multirow[b]{2}{*}{ Parameter } & \multicolumn{4}{|c|}{ Chemical properties } \\
\hline & TKKS & ATKS & $\begin{array}{l}\text { Dregs } \\
\mathrm{mg} / \mathrm{kg}\end{array}$ & Fly ash \\
\hline $\begin{array}{l}\text { pH H2O } \\
\mathrm{C} \text {-Organik } \\
\mathrm{C} / \mathrm{N}\end{array}$ & $\begin{array}{l}7,4 \\
17,8 \% \\
10\end{array}$ & $\begin{array}{l}10,71 \\
4,61 \%\end{array}$ & 9,3 & 12 \\
\hline
\end{tabular}




\begin{tabular}{|l|l|l|l|l|}
\hline N-Total & $1,71 \%$ & $0,14 \%$ & & \\
P-Total & & $1309,97 \mathrm{mg} / 100 \mathrm{~g}$ & & \\
$\mathrm{~K}$ Total & & $57,40 \mathrm{mg} / 100 \mathrm{~g}$ & & \\
$\mathrm{P} 2 \mathrm{OS}$ & $2,71 \%$ & & 2000 & 3600 \\
$\mathrm{~K} 2 \mathrm{O}$ & $2,52 \%$ & & 3100 & 9900 \\
$\mathrm{CaO}$ & $1,12 \%$ & & 410300 & 66700 \\
$\mathrm{MgO}$ & $0,45 \%$ & & 239000 & 8200 \\
$\mathrm{Na}$ & & & 268000 & 2300 \\
$\mathrm{~S}$ & & & 7200 & 5800 \\
$\mathrm{Cl}$ & & & 14067 & 59 \\
$\mathrm{Fe}$ & & & 5000 & 19005 \\
$\mathrm{Mn}$ & & & 989 & 452 \\
$\mathrm{Cu}$ & & & 127 & 26 \\
$\mathrm{Zn}$ & & & 224 & 48 \\
$\mathrm{Co}$ & & 1,7 & 12 \\
$\mathrm{Mo}$ & & 1,2 & 1,5 \\
$\mathrm{Ba}$ & & 350 & 50 \\
$\mathrm{Cd}$ & & 0,2 & 13,5 \\
$\mathrm{Cr}$ & & 167 & 61,4 \\
$\mathrm{Ni}$ & & 98,6 & 42,6 \\
$\mathrm{~Pb}$ & & 8,9 & 6 \\
$\mathrm{Se}$ & & & 355 & $<1$ \\
\hline
\end{tabular}

High availability of $\mathrm{P}$ and $\mathrm{K}$ from the four ameliorants used, as well as high $\mathrm{Ca}$ availability from dregs and fly ash are able to meet the needs of $\mathrm{P}, \mathrm{K}$ and $\mathrm{Ca}$ that are needed by corn. increase root dry weight because $P$ affects the growth of seeds, roots, flowers and fruit. Element $\mathrm{K}$ is also very instrumental in stimulating the growth of plant roots, with improved root structure, the absorption of nutrients will be better. [8] states that the elements $\mathrm{P}$ and $\mathrm{K}$ play a role in the development of the root system so that it becomes better. Optimal rooting will support the supply of nutrients into the plant tissue so that it will support the growth of corn plants. [9] in Masdar (2003) stated that naturally $\mathrm{K}$ diffuses through the soil to the roots of plants, and $\mathrm{K}$ gives a real effect on plant growth. The high $\mathrm{CaO}$ content of dregs and fly ash is able to meet the needs of $\mathrm{Ca}$. The element $\mathrm{Ca}$ also plays a very important role at the root growth point, $\mathrm{Ca}$ deficiency causes the formation and growth of the root to be disrupted so that nutrient absorption becomes inhibited. [10] stated that there was an increase in root volume and the availability of the number and types of essential nutrients due to dregs and $\mathrm{P}$, thus increasing water absorption by plants which resulted in an increase in physiological and metabolic processes in plants. The availability of nutrients is increasing and the absorption of nutrients that goes well, it will improve the physiological process and will affect the dry weight of plants, because the available nutrients can be utilized for the growth of corn biomass. [1] states that the rapid growth of plants is inseparable from the availability of nutrients present in the soil, the availability of nutrients will greatly determine the production of dry weight. During the vegetative phase, the decomposition and dissolution of nutrients from ameliorant continues, so that the nutrients needed by corn plants become available, because it has undergone decomposition of the results of overhaul of organic matter by microorganisms, such as $\mathrm{P}, \mathrm{K}$ and $\mathrm{Ca}$ which are very instrumental in root development. High availability of $P$ and $\mathrm{K}$ from the four ameliorants used, as well as high $\mathrm{Ca}$ availability from dregs and fly ash are able to meet the needs of $\mathrm{P}, \mathrm{K}$ and $\mathrm{Ca}$ that are needed by corn. The $\mathrm{P}$ element plays a role in increasing root dry weight because $P$ affects the growth of seeds, roots, flowers and fruit. Element $\mathrm{K}$ is also very instrumental in stimulating the growth of plant roots, with improved root structure, the absorption of nutrients will be better. [11] [12] states that the elements $P$ and $K$ play a role in the development of the root system so that it becomes better. Optimal rooting will support the supply of nutrients into the plant tissue so that it will support the growth of corn plants. [9] in Masdar (2003) stated that naturally K diffuses through the soil to the roots of plants, and $\mathrm{K}$ gives a real effect on plant growth. The high $\mathrm{CaO}$ content of dregs and fly ash is able to meet the needs of $\mathrm{Ca}$. The element $\mathrm{Ca}$ also plays a very important role at the root growth point, Ca deficiency causes the formation and growth of the root to be disrupted so that nutrient absorption becomes inhibited. [10] stated that there was an increase in root volume and the availability of the number and types of essential nutrients due to dregs and $\mathrm{P}$, thus increasing water absorption by plants which resulted in an increase in physiological and metabolic processes in plants. The availability of nutrients is increasing and the absorption of nutrients that goes well, it will improve the physiological process and will affect the dry weight of plants, because the available nutrients can be utilized for the growth of corn biomass. [13] states that the rapid growth of plants is inseparable from the availability of nutrients present in the soil, the availability of nutrients will greatly determine the production of dry weight.
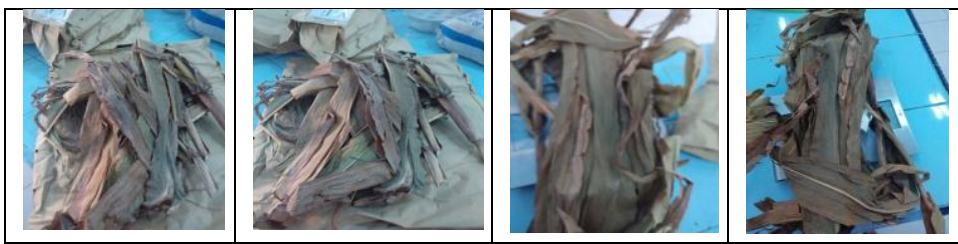

Figure 1. Dry hay display

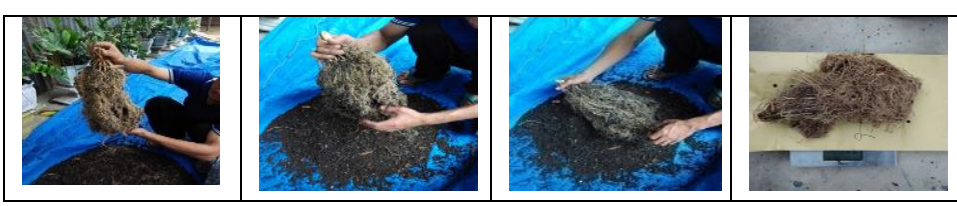

Figure 2. Root Performance

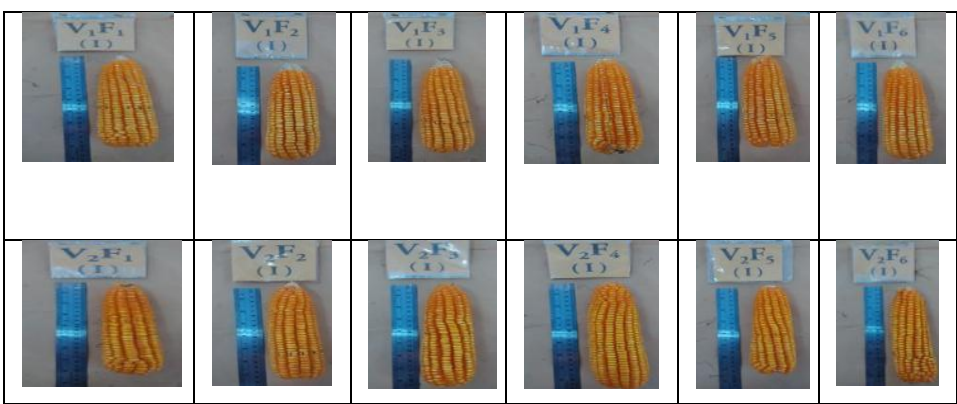

Figure 3. Diameter of Cob and Cob Cob Locations without Kelobot

Optimal rooting will support the supply of nutrients into the plant tissue so that it will support the growth of corn plants. [9] in Masdar (2003) stated that naturally K diffuses through the soil to the roots of plants, and $\mathrm{K}$ gives a real effect on plant growth.

The high $\mathrm{CaO}$ content of dregs and fly ash is able to meet the needs of $\mathrm{Ca}$. The element $\mathrm{Ca}$ also plays a very important role at the root growth point, Ca deficiency causes the formation and growth of the root to be disrupted so that nutrient absorption becomes inhibited. [10] stated that there was an increase in root volume and the availability of the number and types of essential nutrients due to dregs and $\mathrm{P}$, thus increasing water absorption by plants which resulted in an increase in physiological and metabolic processes in plants. The availability of nutrients is increasing and the absorption of nutrients that goes well, it will improve the physiological process and will affect the dry weight 
of plants, because the available nutrients can be utilized for the growth of corn biomass. [12][4] states that the rapid growth of plants is inseparable from the availability of nutrients present in the soil, the availability of nutrients will greatly determine the production of dry-trimmed weight. Variation of ameliorant formulations (Table 4) shows that the administration of various ameliorant formulations to maize varieties Pertiwi-3 and NK212 , had the same effect on the diameter of the cob, the weight of the cob with weighted, the weight of the cob without the kelobot and the dry grain weight. The performance of the diameter of the cob, the weight of the cob with cob and the weight of the cob without knots can be seen in Figures 3 and 4, where in the picture it can be seen that the cob is large and long and the kelobot closes the cob well $( \pm 98 \%)$, straight seed rows with 15-16 rows, and uniform diversity of plants, according to the description. This is because the availability of nutrients due to the provision of various ameliorant formulations has been able to meet the nutrient needs of corn plants. The process of nutrient availability that continues to run from the ameliorant provided, causes the available nutrients to be sufficient and balanced. Increased nutrient availability will increase nutrient uptake by plants, so that photosynthesis takes place perfectly and will spur physiological processes and plant metabolism, so that it will produce photosynthates in the form of good cob. [14] states that cob growth is highly dependent on the rate of photosynthetic activity. [15] added that plants can absorb nutrients well. if the nutrients supplied are sufficient, so that plants can grow and produce well. Besides being used as fertilizer, Amelioran also contains a number of nutrients that are important for plants. The nutrients available from the administration of ameliorant can increase the activity of microorganisms in peat soils and can accelerate the process of decomposition of organic matter, so that the nutrients needed by plants in peat soils are increasingly available and can support the growth and production of corn plants. [16] stated that, the sufficient need for plant nutrients both macro and micro elements, will increase plant growth and productivity[17].

\section{CONCLUSION}

Interaction of varieties with ameliorant formulations has the same effect on vegetative growth and production, with large and long ear cobs and knobs covering the cob well ( $\pm 98 \%)$, straight seed rows with number of 15-16 rows, and plant diversity uniform, in accordance with the description

\section{REFFERENCE}

[1] Marlina, Armaini, and Nelvia, "PERTUMBUHAN DAN HASIL DUA VARIETAS JAGUNG," vol. 7, no. 2, pp. 21-28, 2017.

[2] M. Apriyanto and E. Harmayani, "Study on effect of fermentation to the quality parameter of cocoa bean in Indonesia," Asian J. Dairy Food Res, vol. 35, no. 2, pp. 160-163, 2016.

[3] M. Apriyanto, S. Sutardi, E. Harmayani, and S. Supriyanto, "Perbaikan Proses Fermentasi Biji Kakao Non Fermentasi dengan Penambahan Biakan Murni Saccharomyces cerevisiae, Lactobacillus lactis, dan Acetobacter aceti," AGRITECH, vol. 36, no. 4, 2016.

[4] I. Sasli, F. Pertanian, U. Tanjungpura, and J. A. Y. Pontianak, "Karakterisasi gambut dengan berbagai bahan amelioran dan pengaruhnya terhadap sifat fisik dan kimia guna mendukung produktivitas lahan gambut," vol. 4, no. 1, pp. 42-50, 2011.
[5] K. Tanah, E. Co, D. A. N. Produktivitas, S. J. Fitra, and S. Prijono, "PENGARUH PEMUPUKAN PADA LAHAN GAMBUT TERHADAP The Effect of Fertilization of Peat Land on Soil Characteristics, CO 2 Emissions , and Productivity of Rubber Plant," vol. 6, no. 1, pp. 1145-1156, 2019.

[6] A. Dariah et al., "KARAKTERISTIK LAHAN GAMBUT Sifat Fisik Tanah Gambut Kematangan Gambut," pp. 16-29, 2013.

[7] D. I. Lahan et al., "M a It a," 2008.

[8] A. I. A. Stefanny, Nelvia, "1 , 2 3."

[9] K. Petani, J. Lahan, and K. Barat, "DI DESA LIMBUNG , KABUPATEN PONTIANAK," 2000.

[10] H. Fauzana, A. Alfasiri, and N. Nelvia, "SIFAT KIMIA TANAH DAN POPULASI KUMBANG TANDUK (Oryctes rhinoceros L.) STADIA PRADEWASA PADA BERBAGAI KEDALAMAN PENEMPATAN TANDAN KOSONG KELAPA SAWIT," J. Solum, vol. 16, no. 1, p. 1, 2019.

[11] M Apriyanto, Sutardi, Supriyadi, Eni Harmayani, "Fermentasi biji kakao kering menggunakan Saccharomycescerevisiae, Lactobacillus lactis , Acetobacter aceti," AGRITECH, vol. 37, no. 3, pp. 302311, 2017.

[12] E. Aryanti and A. R. Annisava, "( Giving Some Ameliorants To Changes Chemical Properties of Peat Soil )," vol. 7, no. 1, pp. 19-26, 2016.

[13] B. G. M, B. W. Simanihuruk, and J. Arto, "Pertumbuhan dan hasil jagung pada lahan gambut dengan penerapan teknologi tampurin," vol. 6, no. 1, pp. 14-21, 2004.

[14] M. Apriyanto and M. C. B. Umanailo, "Decrease Polyphenols, Ethanol , Lactic Acid, and Acetic Acid during Fermentation with Addition of Cocoa Beans Innoculum," vol. 8, no. 10, pp. 461-465, 2019.

[15] M. Octvaiana, "Agrotechnology Departement , Agriculture Faculty , University of Riau," 2010.

[16] S. Kartawisastra and S. Survey, "LAHAN GAMBUT INDONESIA," no. August 2016, 2018.

[17] M. Apriyanto, "PELATIHAN DAN PENDAMPINGAN PENGOLAHAN KOMODITAS KELAPA," J. Pengabdi. DAN Pemberdaya. Masy., vol. 3, no. 2, 2019. 